Bull. Chem. Soc. Ethiop. 2014, 28(2), 255-264.

ISSN 1011-3924

Printed in Ethiopia

DOI: http://dx.doi.org/10.4314/bcse.v28i2.9

(C) 2014 Chemical Society of Ethiopia

\title{
SYNTHESIS, CHARACTERIZATION, BIOLOGICAL AND ELECTRICAL CONDUCTIVITY STUDIES OF SOME SCHIFF BASE METAL COMPLEXES
}

\author{
Amit R. Yaul, Vijaya V. Dhande, Gaurav B. Pethe and Anand S. Aswar* \\ Department of Chemistry, Sant Gadge Baba Amravati University, Amravati-444602, M.S., India
}

(Received July 11, 2013; revised March 20, 2014)

\begin{abstract}
Metal complexes of $\mathrm{VO}(\mathrm{IV}), \mathrm{Zr}(\mathrm{IV}), \mathrm{Th}(\mathrm{IV})$ and $\mathrm{UO}_{2}(\mathrm{VI})$ with Schiff base ligands derived from 4-nitrobenzoylhydrazide with 2-hydroxy-5-methylacetophenone $\left(\mathrm{H}_{2} \mathrm{~L}^{1}\right)$ or 2-hydroxy-5-chloroacetophenone $\left(\mathrm{H}_{2} \mathrm{~L}^{2}\right)$ have been prepared. All the complexes have been characterized on the basis of elemental analyses, magnetic susceptibility measurement, electronic and IR spectra and thermogravimetric analysis. The IR spectral data suggested that the ligands behave as dibasic tridentate moiety towards the central metal ion coordinating through phenolic oxygen, enolic oxygen and azomethine nitrogen atoms. The elemental analyses show a 1:1 metal:ligand stoichiometry for all the complexes except Th(IV) which has 1:2 stoichiometry. The thermal analysis evidenced that thermal transformations of complexes are processes according to TG curves including dehydration, thermolysis and oxidative degradation of Schiff base. The final product of decomposition is the most stable metallic oxide. The kinetic analysis of the thermogravimetric data was performed by using the Coats-Redfern method. Solid state electrical conductivity of the complexes has been measured in their compressed pellet form over a 310-413 K temperature range. All the complexes show semiconducting behavior as their conductivity increases with increasing temperature and a function of ionic size. All the complexes along with ligands were also screened for their antibacterial and antifungal activities.
\end{abstract}

KEY WORDS: Aroylhydrazones, Metal complexes, Biological activity, TGA, Electrical conductivity

\section{INTRODUCTION}

Hydrazones constitute an important class of compounds with a wide spectrum of pharmacological properties. They are known to possess a wide range of biological applications. The acid hydrazides have gained importance due to their remarkable applications in the medicinal field. As these compounds are known to have good biological activities related to the coordination of bio-metals, the methyl hydrazones can be used in chelation therapy as they have potential binding sites which form stable complexes. These ligands can exhibit keto-enol tautomerism. Metal complexes of aroylhydrazones have broad applications in biological processes such as in the treatment of tumor, tuberculosis, leprosy and mental disorder $[1,2]$. The tendency of aroylhydrazones to give intensely coloured metal chelates allows their use as extraction reagents for the spectroscopic determination of several metal ions [3, 4]. Literature survey reveals that much attention has been paid to the study of aroylhydrozone complexes derived from aliphatic, aromatic and heteroaromatic aldehydes [5-8]. Most studies are focused on complexes of d-block elements, especially those of the first series. However, reports of aroylhydrazones derived from substituted acetophenone and their complexes with higher valent elements are scarce. Hence, it was thought of interest to carry out systematic investigation on $\mathrm{VO}(\mathrm{IV}), \mathrm{Zr}(\mathrm{IV}), \mathrm{Th}(\mathrm{IV})$ and $\mathrm{UO}_{2}(\mathrm{VI})$ complexes of hydrazones derived from 4-nitrobenzoylhydrazide with 2-hydroxy-5-methylacetophenone or 2-hydroxy-5-chloroacetophenone.

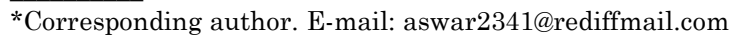


Materials and methods

\section{EXPERIMENTAL}

All the chemicals used were of analytical reagent grade. 2-Hydroxy-5-methylacetophenone and 2-hydroxy-5-chloroacetophenone were prepared by Fries migration of methyl and chlorophenyl acetates using anhydrous aluminium chloride in absence of solvent. Zirconium(IV) acetate was prepared by reported method [9]. Vanadyl sulfate and nitrates of Th(IV) and $\mathrm{UO}_{2}(\mathrm{VI})$ were used of SD's fine chemical as received. Microanalyses of carbon, hydrogen and nitrogen of the complexes were carried on a Vario EL-III elemental analyzer at SAIF, CDRI, Lucknow, India. Metal content in each complex was determined gravimetrically by decomposing the complexes with conc. $\mathrm{HNO}_{3}$ and then igniting to metal oxides [10]. The IR spectra were recorded on a Perkin Elmer Infrared Spectrophotometer in the range $4000-400 \mathrm{~cm}^{-1}$ at CDRI, Lucknow, India. Solid-state electronic spectra of the complexes were recorded on a carry 2300 spectrophotometer at SAIF, Chennai, India. ${ }^{1} \mathrm{H}-\mathrm{NMR}$ spectra of ligands were recorded on a Bruker AC 250 spectrometer at $250 \mathrm{MHz}$, using TMS as a reference in DMSO- $\mathrm{d}_{6}$. The magnetic susceptibilities at room temperature were measured on a Gouy's balance using $\mathrm{Hg}\left[\mathrm{Co}(\mathrm{NCS})_{4}\right]$ as the calibrant. Diamagnetic corrections for various atoms and structural units were computed using Pascal's constants. TG analysis of the complexes was carried out on Perkin Elmer TG-2 thermobalance in ambient air with a heating rate of $10{ }^{\circ} \mathrm{C} / \mathrm{min}$. The electrical conductivity was measured as a function of temperature (310-413 K) by using a Zentech electrometer. The samples were in the form of pellets of diameter $13 \mathrm{~mm}$ diameter and thickness of which were pressed under a pressure of $c a 3$ ton $\mathrm{cm}^{-2}$. Good contact area was achieved by liquid silver painting on the two opposite surfaces of each pellet. The temperature was measured in air using $\mathrm{Cu}-\mathrm{Ni}$ thermocouple placed closed to sample. Antibacterial and antifungal activities of the ligands and their complexes were tested against the bacteria E. coli, S. abony, P. aeruginosa, S. aureus and B. subtilis and fungi A. niger and C. albicans by the agar cup plate method [11]. A DMSO system was used as control in this method. The area of inhibition was measured in millimeters.

\section{Synthesis of hydrazone ligands}

The hydrazone ligands $\mathrm{H}_{2} \mathrm{~L}^{1}$ and $\mathrm{H}_{2} \mathrm{~L}^{2}$ used in the present work were prepared by condensation of 2-hydroxy-5-methylacetophenone or 2-hydroxy-5-chloroacetophenone and 4-nitrobenzoylhydrazide according to the following procedure $[12,13]$ : into a two neck flask equipped with a reflux condenser was placed an ethanolic solution of 2-hydroxy-5-methylacetophenone (50 $\mathrm{mmol}, 30 \mathrm{~mL}$ ) or 2-hydroxy-5-chloroacetophenone $(50 \mathrm{mmol})$. To this solution 4-nitrobenzoylhydrazide was added drop wise $(50 \mathrm{mmol}, 40 \mathrm{~mL})$ within about $2-3 \mathrm{~min}$. The resulting reaction mixture was then refluxed for $4 \mathrm{~h}$ on a water bath. On cooling to the room temperature yellow colored solid was obtained. The resulting solid mass was filtered, washed several times with ethanol, diethyl ether and subsequently dried over $\mathrm{CaCl}_{2}$ in a desiccator.

\section{Synthesis of metal complexes}

All the complexes were prepared according to the procedure: an ethanolic solution of hydrated $\mathrm{UO}_{2}(\mathrm{VI}) / \mathrm{Th}(\mathrm{IV}) /$ vanadyl sulfate $(0.01 \mathrm{~mol})$ was added to a hot ethanolic solution of ligands $\mathrm{H}_{2} \mathrm{~L}^{1}$ or $\mathrm{H}_{2} \mathrm{~L}^{2}(0.01 \mathrm{~mol})$ [in case of $\mathrm{UO}_{2}(\mathrm{VI})$ and $\mathrm{VO}(\mathrm{IV})$ complexes methanol and DMF respectively were used as solvents in place of ethanol]. The resulting mixture was then refluxed for 5-6 h on a sand bath during which a colored complex was precipitated out in each case. The separated complexes were filtered off, washed several times with ethanol to remove any traces of unreacted starting materials, then washed with petroleum ether, and dried in a vacuum desiccators over anhydrous $\mathrm{CaCl}_{2}$, yield $=68-73 \%$. 
Synthesis of $\mathrm{Zr}(\mathrm{OH})_{2} \mathrm{~L}\left(\mathrm{CH}_{3} \mathrm{OH}\right)_{2}$

Freshly prepared zirconium(IV) acetate $(0.001 \mathrm{~mol})$ was allowed to react with the Schiff base $(0.001 \mathrm{~mol})$ in methanol $(20 \mathrm{~mL})$ under reflux conditions for $2 \mathrm{~h}$. The contents were cooled to room temperature. A methanolic solution $(10 \mathrm{~mL})$ of sodium methoxide $(0.002 \mathrm{~mol})$ was added and the mixture stirred magnetically for $5 \mathrm{~min}$. The mixture was further refluxed for $2 \mathrm{~h}$. The separated yellow precipitates were filtered, washed with methanol and dried in vacuo at room temperature, yield $=75 \%$.

\section{RESULTS AND DISCUSSION}

All the complexes are dark coloured solids and insoluble in most of the common organic solvents such as ethanol, methanol, acetone, ether but found soluble in DMF and DMSO. They are highly stable under normal conditions and all of them decompose at higher temperature. Analytical data (Table 1) suggest a 1:1 metal:ligand stoichiometry for all the complexes except Th(IV) which has 1:2 stoichiometry. For ligand $\left(\mathrm{H}_{2} \mathrm{~L}^{1}\right)$, the ${ }^{1} \mathrm{H}-\mathrm{NMR}$ shows signals at $\delta 12.95$ $(1 \mathrm{H}, \mathrm{s}$, phenolic $\mathrm{OH}), 11.34(1 \mathrm{H}, \mathrm{s}$, imino $)$ 7.95-7.30 $(7 \mathrm{H}, \mathrm{m}, \mathrm{Ar}-\mathrm{H}), 3.22(3 \mathrm{H}, \mathrm{s}$, methyl) and $2.44\left(3 \mathrm{H}, \mathrm{s}\right.$, Ar-methyl). For ligand $\left(\mathrm{H}_{2} \mathrm{~L}^{2}\right)$, the ${ }^{1} \mathrm{H}-\mathrm{NMR}$ signals appear at $\delta 12.74(1 \mathrm{H}, \mathrm{s}$, phenolic $\mathrm{OH}) ; 11.20(1 \mathrm{H}, \mathrm{s}$, imino), $8.00-7.25(7 \mathrm{H}, \mathrm{m}, \mathrm{Ar}-\mathrm{H})$ and $3.20(3 \mathrm{H}, \mathrm{s}$, methyl) [14].

Table 1. Analytical and physical data of ligands and their complexes.

\begin{tabular}{|c|c|c|c|c|c|c|}
\hline \multirow[b]{2}{*}{ Compound } & \multirow[b]{2}{*}{ Colour } & \multicolumn{4}{|c|}{ Elemental analyses \% found (calcd.) } & \multirow{2}{*}{$\begin{array}{c}\text { Electrical } \\
\text { conductivity } \\
\sigma\left(\Omega^{-1} \mathrm{~cm}^{-1}\right)\end{array}$} \\
\hline & & $\mathrm{C}$ & $\mathrm{H}$ & $\mathrm{N}$ & M & \\
\hline $\mathrm{H}_{2} \mathrm{~L}^{1}$ & Pale yellow & $\begin{array}{c}53.85 \\
(53.97) \\
\end{array}$ & $\begin{array}{c}3.59 \\
(3.62) \\
\end{array}$ & $\begin{array}{c}12.48 \\
(12.59) \\
\end{array}$ & -- & -- \\
\hline $\mathrm{H}_{2} \mathrm{~L}^{2}$ & Yellow & $\begin{array}{l}61.16 \\
(61.33) \\
\end{array}$ & $\begin{array}{c}5.33 \\
(4.82) \\
\end{array}$ & $\begin{array}{c}12.87 \\
(13.41)\end{array}$ & -- & -- \\
\hline$\left[\mathrm{VOL}^{1}\left(\mathrm{H}_{2} \mathrm{O}\right)\right]$ & Dark olive & $\begin{array}{c}48.32 \\
(48.37)\end{array}$ & $\begin{array}{c}4.00 \\
(3.85)\end{array}$ & $\begin{array}{c}10.61 \\
(10.58) \\
\end{array}$ & $\begin{array}{c}12.79 \\
(12.06)\end{array}$ & $2.40 \times 10^{-8}$ \\
\hline$\left[\mathrm{Zr}(\mathrm{OH})_{2} \mathrm{~L}^{1}\left(\mathrm{CH}_{3} \mathrm{OH}\right)_{2}\right]$ & \begin{tabular}{|l} 
Cannery \\
yellow
\end{tabular} & $\begin{array}{c}43.15 \\
(43.18) \\
\end{array}$ & $\begin{array}{c}4.60 \\
(4.63) \\
\end{array}$ & $\begin{array}{c}8.31 \\
(8.39) \\
\end{array}$ & $\begin{array}{c}18.16 \\
(18.22) \\
\end{array}$ & $3.06 \times 10^{-9}$ \\
\hline$\left[\mathrm{Th}\left(\mathrm{HL}^{1}\right)_{2}\left(\mathrm{NO}_{3}\right)_{2}\right]$ & $\begin{array}{l}\text { Cannery } \\
\text { yellow }\end{array}$ & $\begin{array}{c}39.78 \\
(39.19) \\
\end{array}$ & $\begin{array}{c}2.42 \\
(2.88)\end{array}$ & $\begin{array}{c}12.05 \\
(11.43)\end{array}$ & $\begin{array}{c}24.10 \\
(23.66)\end{array}$ & $7.00 \times 10^{-10}$ \\
\hline$\left[\mathrm{UO}_{2} \mathrm{~L}^{1}\left(\mathrm{CH}_{3} \mathrm{OH}\right)\right]$ & Volcana & $\begin{array}{c}28.39 \\
(29.10) \\
\end{array}$ & $\begin{array}{c}2.62 \\
(2.76)\end{array}$ & $\begin{array}{c}6.80 \\
(6.98) \\
\end{array}$ & $\begin{array}{c}35.22 \\
(35.86)\end{array}$ & $3.00 \times 10^{-9}$ \\
\hline$\left[\mathrm{VOL}^{2}\left(\mathrm{H}_{2} \mathrm{O}\right)\right]$ & $\begin{array}{l}\text { Tata } \\
\text { Memosa } \\
\end{array}$ & $\begin{array}{c}42.98 \\
(43.12) \\
\end{array}$ & $\begin{array}{c}2.90 \\
(2.99) \\
\end{array}$ & $\begin{array}{c}10.01 \\
(10.06) \\
\end{array}$ & $\begin{array}{c}12.08 \\
(12.19) \\
\end{array}$ & $1.99 \times 10^{-8}$ \\
\hline$\left[\mathrm{Zr}(\mathrm{OH})_{2} \mathrm{~L}^{2}\left(\mathrm{CH}_{3} \mathrm{OH}\right)_{2}\right]$ & Primrose & $\begin{array}{c}39.21 \\
(39.18)\end{array}$ & $\begin{array}{c}3.80 \\
(3.86)\end{array}$ & $\begin{array}{c}7.99 \\
(8.06)\end{array}$ & $\begin{array}{c}17.42 \\
(17.50)\end{array}$ & $2.00 \times 10^{-9}$ \\
\hline$\left[\mathrm{Th}\left(\mathrm{HL}^{2}\right)_{2}\left(\mathrm{NO}_{3}\right)_{2}\right]$ & Yellow & $\begin{array}{l}25.03 \\
(25.53)\end{array}$ & $\begin{array}{c}1.13 \\
(1.71)\end{array}$ & $\begin{array}{l}10.12 \\
(9.92) \\
\end{array}$ & $\begin{array}{c}33.06 \\
(32.88) \\
\end{array}$ & $5.00 \times 10^{-8}$ \\
\hline$\left[\mathrm{UO}_{2} \mathrm{~L}^{2}\left(\mathrm{CH}_{3} \mathrm{OH}\right)\right]$ & Primrose & $\begin{array}{c}29.50 \\
(30.32) \\
\end{array}$ & $\begin{array}{c}2.11 \\
(2.23) \\
\end{array}$ & $\begin{array}{c}6.59 \\
(6.62) \\
\end{array}$ & $\begin{array}{c}36.12 \\
(37.56) \\
\end{array}$ & $2.50 \times 10^{-9}$ \\
\hline
\end{tabular}

Infrared spectra

A comparison of the IR spectra of the complexes and the ligands shows that the $v(C=O)$ band of the ligands appearing at $\sim 1652 \mathrm{~cm}^{-1}$ and the $\mathrm{v}(\mathrm{NH})$ mode at $3222-3232 \mathrm{~cm}^{-1}$ are absent in the spectra of all the complexes except Th(IV) complexes. This is presumably due to keto-enol tautomerism (Figure 1) of the ligands and their subsequent coordination through the enolic 
oxygen [15]. This is further evidenced by the appearance of a new band in the spectra of the complexes at $1507-1539 \mathrm{~cm}^{-1}$ attributed to the azine group $>\mathrm{C}=\mathrm{N}-\mathrm{N}=\mathrm{C}<$, which is absent in the spectra of the hydrazone ligands. The presence of medium intensity band at $1330-1370 \mathrm{~cm}^{-1}$ in the complexes are assigned to $v(\mathrm{C}-\mathrm{O})$ due to coordination of the enolic oxygen after deprotonation [16]. This supports the view that the amide oxygen is bonded in the enolic form upon deprotonation in each case. The enolization is favoured by the stabilization of the anion by the conjugation with the $>\mathrm{C}=\mathrm{N}-\mathrm{N}=\mathrm{C}<$ group [17]. The IR spectra of $\mathrm{Th}(\mathrm{IV})$ complexes display $v(\mathrm{~N}-\mathrm{H})$ and $v(\mathrm{C}=\mathrm{O})$ bands suggesting that ligands remains in their keto form. In the spectra of complexes $v(C=N)$ (azomethine) mode of the hydrazones $\sim 1600 \mathrm{~cm}^{-1}$ shifts to lower wave numbers indicating the coordination of the azomethine nitrogen [18]. The coordination through the azomethine nitrogen is further substantiated by the observed shift to higher wave number by $\sim 30 \mathrm{~cm}^{-1}$ in the $v(\mathrm{~N}-\mathrm{N})$ mode in the complexes. The magnitude of this shift indicates the monodentate coordination of the $>\mathrm{N}-\mathrm{N}<$ moiety, as a shift of $>50 \mathrm{~cm}^{-1}$ is usually observed in bidentate coordination [19].

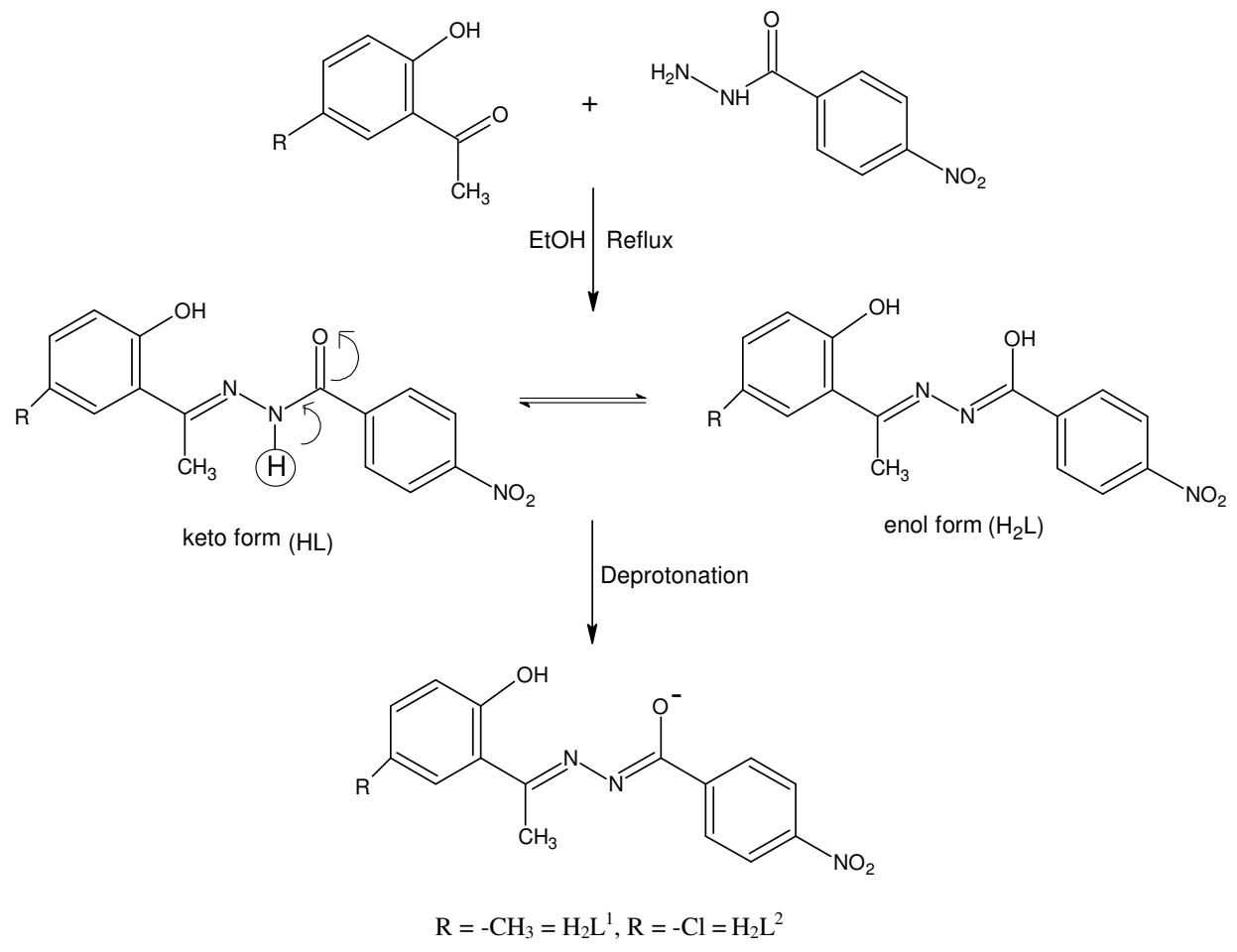

Figure 1. Keto-enol tautomerism of hydrozone ligands.

The strong IR bands in the range 959-962, 1130-1135 and $\sim 908 \mathrm{~cm}^{-1}$ in $\mathrm{VO}(\mathrm{IV}), \mathrm{Zr}(\mathrm{IV})$ and $\mathrm{UO}_{2}(\mathrm{VI})$ complexes are assigned to $\mathrm{v}(\mathrm{V}=\mathrm{O}), \mathrm{Zr}-\mathrm{OH}$ and $\mathrm{O}=\mathrm{U}=\mathrm{O}$ vibrations, respectively [20]. In the spectra of $\mathrm{Th}(\mathrm{IV})$ complexes, the two additional medium intensity bands observed around $\sim 1390$ and $\sim 1055 \mathrm{~cm}^{-1}$ are assigned to $v_{4}$ and $v_{1}$ vibrations, respectively of the coordinated nitrate ion. The difference in magnitude of transitions indicates that the nitrato group is coordinated to the thorium ion in a monodentate fashion [21]. A new strong band at 1230-1260

Bull. Chem. Soc. Ethiop. 2014, 28(2) 
$\mathrm{cm}^{-1}$ in the spectra of $\mathrm{Zr}(\mathrm{OH})_{2} \mathrm{~L} 2 \mathrm{CH}_{3} \mathrm{OH}$ is assigned to the $\mathrm{v}(\mathrm{C}-\mathrm{O})$ (enolic). The $v(\mathrm{C}-\mathrm{O})$ of $\mathrm{CH}_{3} \mathrm{OH}$ occurs at $\sim 1034 \mathrm{~cm}^{-1}$ and this band undergoes a negative shift in $\mathrm{Zr}(\mathrm{OH})_{2} \mathrm{~L}\left(\mathrm{CH}_{3} \mathrm{OH}\right)_{2}$ and is observed at $\sim 995 \mathrm{~cm}^{-1}$ indicating methanol coordination [22]. The absence of a new band in the spectra of $\mathrm{Zr}(\mathrm{IV})$ complexes in the range 856-962 $\mathrm{cm}^{-1}$ due to the $\mathrm{v}(\mathrm{Zr}=\mathrm{O})$ and occurrence of a new band in the range $1100-1140 \mathrm{~cm}^{-1}$ due to the $\mathrm{v}(\mathrm{Zr}-\mathrm{O}-\mathrm{H})$ favors the formulation of the complexes as $\mathrm{Zr}(\mathrm{OH})_{2} \mathrm{~L} \cdot\left(\mathrm{CH}_{3} \mathrm{OH}\right)_{2}$ and not as $\mathrm{ZrOL}\left(\mathrm{H}_{2} \mathrm{O}\right)\left(\mathrm{CH}_{3} \mathrm{OH}\right)_{2}$. Non ligand bands occurring in the range 502-467 $\mathrm{cm}^{-1}$ (broad) and 435-408 $\mathrm{cm}^{-1}$ (sharp) have been assigned to $v(\mathrm{M}-\mathrm{O})$ and $v(\mathrm{M}-\mathrm{N})$ respectively, the $v(\mathrm{M}-\mathrm{O})$ band usually occurs at higher energy than the $v(\mathrm{M}-\mathrm{N})$ band. The $v(\mathrm{M}-\mathrm{O})$ band is usually broad and strong while $v(\mathrm{M}-\mathrm{N})$ band is usually strong as a larger dipole moment change in involved in the vibration of $\mathrm{M}-\mathrm{O}$ in comparison with that in the M-N bond [23]. In VO(IV) complexes, the presence of coordinated water is indicated by the presence of a broad band in the region $3200-3500 \mathrm{~cm}^{-1}$.

\section{Magnetic behavior and electronic spectra}

The observed magnetic moments for the VO(IV) complexes are in the range 1.69 and 1.75 B.M. as expected for mononuclear complexes [24]. The $\mathrm{Zr}(\mathrm{IV}), \mathrm{Th}(\mathrm{IV})$ and $\mathrm{UO}_{2}(\mathrm{VI})$ complexes are found to be diamagnetic as expected for their $\mathrm{f}^{0}$ electronic configuration.

The electronic spectra of $\mathrm{VO}(\mathrm{IV})$ complexes show four bands at 13,000;18,000;23,000 and $32,000 \mathrm{~cm}^{-1}$ due to ${ }^{2} \mathrm{~B}_{2} \rightarrow{ }^{2} \mathrm{E},{ }^{2} \mathrm{~B}_{2} \rightarrow{ }^{2} \mathrm{~B}_{1},{ }^{2} \mathrm{~B}_{2} \rightarrow{ }^{2} \mathrm{~A}_{1}$ and charge transfer transitions, respectively, the characteristic features of square pyramidal complexes [25]. The reflectance spectra of the uranyl complexes exhibit bands at $\sim 19,000 ; 23,500$ and $39,000 \mathrm{~cm}^{-1}$ consistent with the vibronic structure of the triatomic entity of $\mathrm{UO}_{2}(\mathrm{VI})$ group.

\section{Thermal study}

Thermal analyses of the compounds were studied under dynamic air atmosphere and it has been observed that the decomposition of complexes involve two steps. The TGA curves for the $\mathrm{H}_{2} \mathrm{~L}^{1}$ and its complexes are as shown in Figures 2-6. The presence of coordinated water molecule in complexes is also confirmed by TGA analysis. The VO(IV) complexes are stable up to $143{ }^{\circ} \mathrm{C}$ and thereafter they register a mass loss of $4.45 \%$ at $145-185^{\circ} \mathrm{C}$ against the theoretical value of $4.58 \%$ which corresponds to the loss of one coordinated water molecule. After $210{ }^{\circ} \mathrm{C}$, the anhydrous complexes start decomposing and continue mass loss was observed up to $700{ }^{\circ} \mathrm{C}$ leaving behind the residue corresponds to stable metal oxides. The $\mathrm{UO}_{2}(\mathrm{VI})$ complexes show mass loss up to $165{ }^{\circ} \mathrm{C}$ corresponding to one methanol molecule which is coordinated to the metal ion to fulfil its coordination centre. The degradation of ligand was observed till $700{ }^{\circ} \mathrm{C}$. After this, the complexes completely convert into metal oxide and mass become stable. The TG curves of zirconyl complexes are almost stable up to $140{ }^{\circ} \mathrm{C}$ indicating the absence of any lattice water molecules, and decomposition begins beyond this temperature due to the loss of methanol molecule. The gradual mass loss of the complexes occurs continue till a constant mass, in which the $\mathrm{ZrO}_{2}$ residue is formed as a final product. Thermograms of $\mathrm{Th}(\mathrm{IV})$ complexes indicate the loss of two equivalent of nitrate per unit of metal complex in the first step. After the total loss of nitrate, the organic moiety decomposes on further increment of temperature. Although decomposed fragments of the ligands could not be estimated due to continuous mass loss, the complete decomposition of ligands occurs at $\sim 700{ }^{\circ} \mathrm{C}$. On further increasing the temperature no mass loss is observed which may be attributed to the formation of stable metal oxide $\mathrm{ThO}_{2}$. 


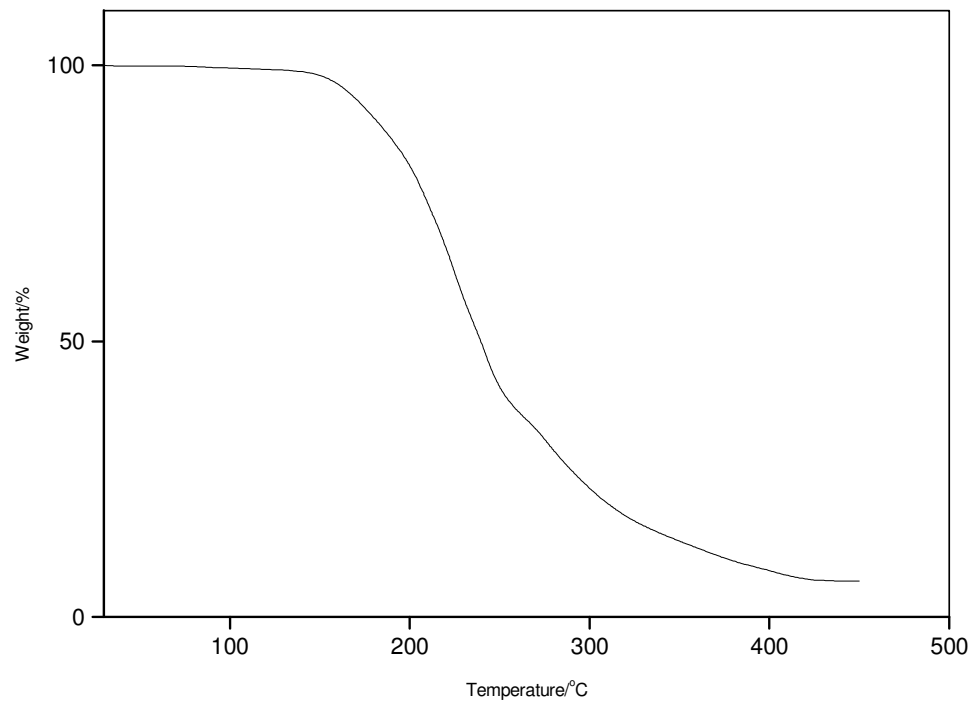

Figure 2. TG curve of $\mathrm{H}_{2} \mathrm{~L}^{1}$ ligand.

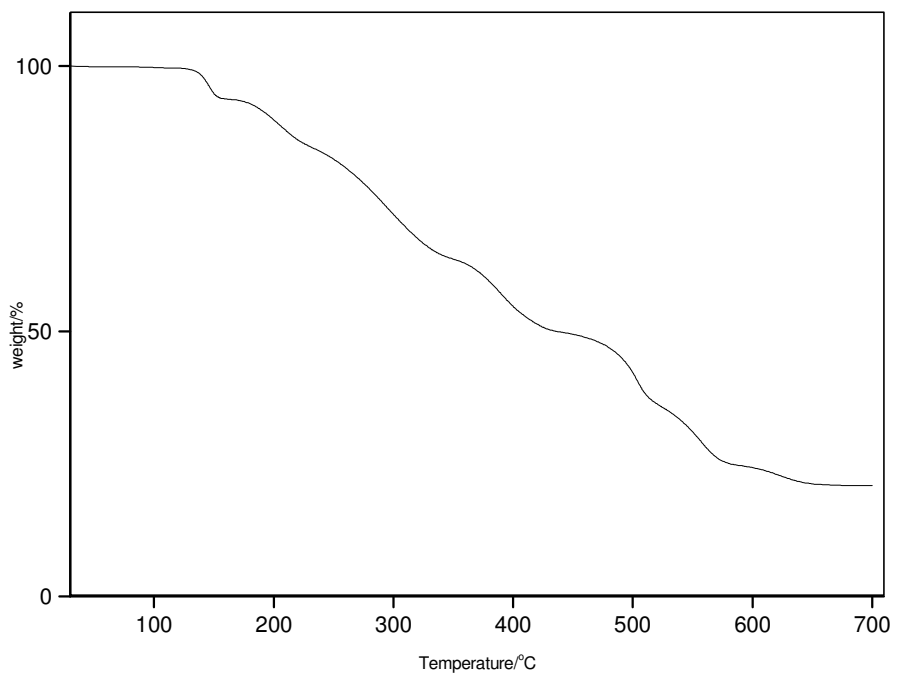

Figure 3. TG curve of $\left[\operatorname{VOL}^{1}\left(\mathrm{H}_{2} \mathrm{O}\right)\right]$ complex. 
Synthesis, biological and electrical conductivity studies of some Schiff base metal complexes 261

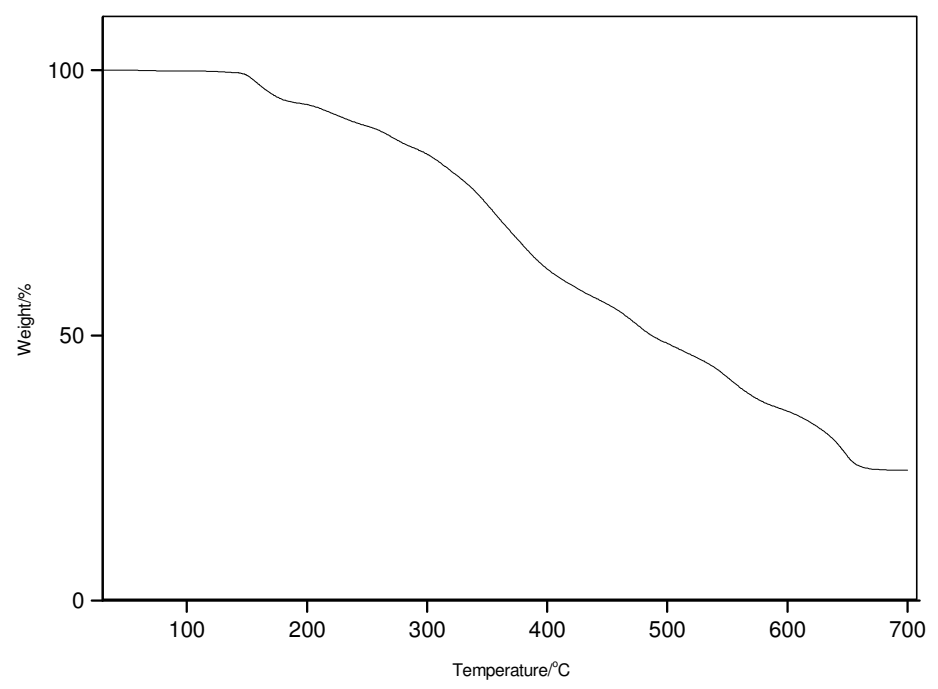

Figure 4. TG curve of $\left[\mathrm{Zr}(\mathrm{OH})_{2} \mathrm{~L}^{1}\left(\mathrm{CH}_{3} \mathrm{OH}\right)_{2}\right]$ complex.

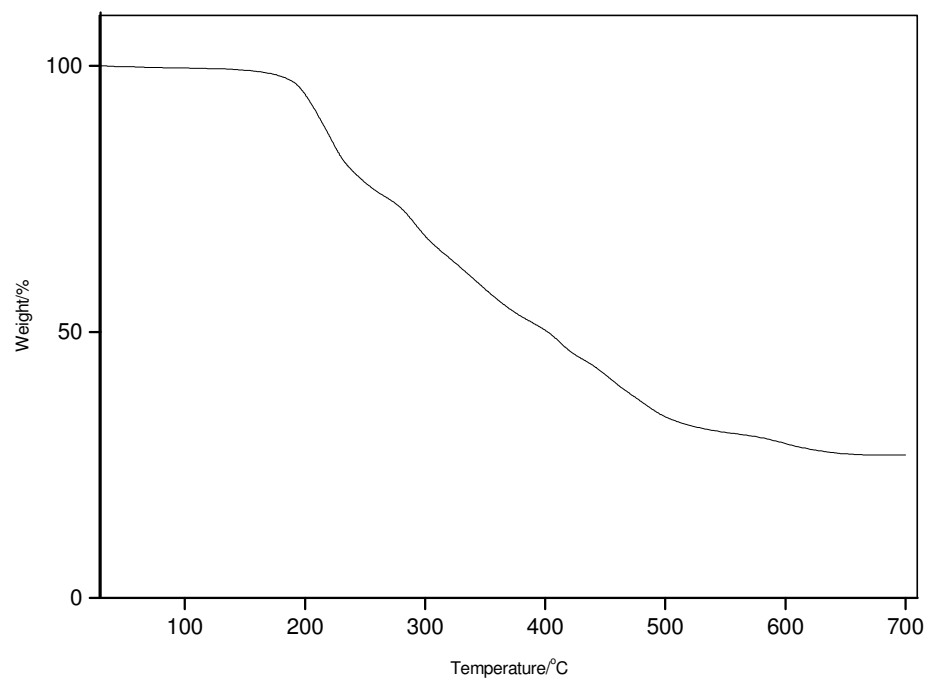

Figure 5. TG curve of $\left[\mathrm{Th}\left(\mathrm{HL}^{1}\right)_{2}\left(\mathrm{NO}_{3}\right)_{2}\right]$ complex. 


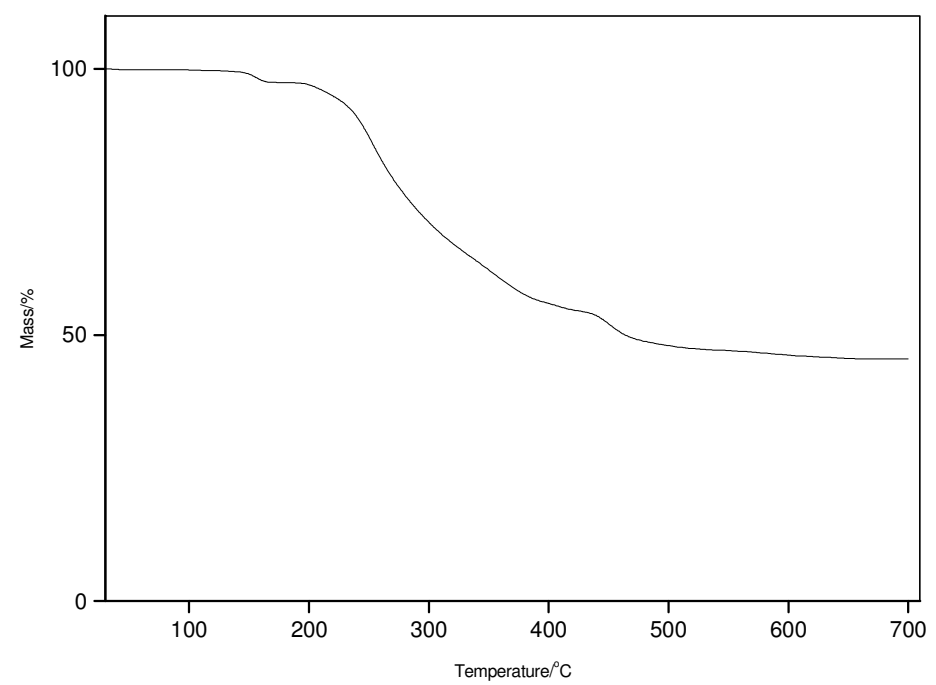

Figure 6. TG curve of $\left[\mathrm{UO}_{2} \mathrm{~L}^{1}\left(\mathrm{CH}_{3} \mathrm{OH}\right)\right]$ complex.

\section{Kinetics of decomposition}

Non-isothermal kinetics of the both decomposition steps of the complexes was studied. The values of the degree of decomposition $(\alpha)$ at different temperatures were obtained from TG curves. From the values of $\alpha$, corresponding $(1-\alpha)^{\mathrm{n}}$ values were calculated where $\mathrm{n}$ depends upon the reaction model. The equation of Coats-Redfern [26] was employed. The model, which corresponds to the linear fit, has been used to give the probable mechanism of the decomposition. From the slope and the intercept, activation energy $(E)$ and frequency factor $(Z)$ values were calculated. Using $E$ and $Z$ values, the values of entropy change $(\Delta S)$ and free energy change $(\Delta \mathrm{G})$ were calculated. The values of $\mathrm{E}, \mathrm{Z}, \Delta \mathrm{S}$ and $\Delta \mathrm{G}$ estimated by Coats-Redfern method are presented in Table 2 . The value of $\Delta S$ is large and negative and small value of $Z$ suggests that the transition state is in highly ordered state than individual reactant and it is a rate-determining step [27, 28]. The kinetic parameters show a somewhat different trend from that of thermal stability. This can be due to the fact the decisive criteria in kinetics are often quite different from those, which decide thermal stability [29].

\section{Electrical conductivity}

The electrical conductivity (dc) of the complexes was studied in the temperature range 310-413 $\mathrm{K}$. In all cases the conductivity increases with increasing temperature indicating that these complexes lie in the range of semiconductors. A plot of $\log \sigma$ vs $1 / \mathrm{T}$ of compounds under investigation obeys the equation: $\sigma=\sigma_{o} \exp (-\mathrm{Ea} / \mathrm{kT})$, the symbols having usual significance [30]. The values of electrical conductivities $(\sigma)$ are listed in Table 1 . The electrical conductivity of the complexes have positive temperature coefficient. That is, with the increase in temperature, conductivity increases exponentially in the measurement range of temperature. The increase starts when charge carriers have enough activation energy. Also, during the increase of temperature the mobility of these carriers increases and this is a property of typical semiconductors [31]. The electrical conductivity of complexes lies in the range $7.00 \times 10^{-10}$ $1.99 \times 10^{-8} \Omega^{-1} \mathrm{~cm}^{-1}$ range at $373 \mathrm{~K}$. The electrical conductivity of complexes follow the order 
$\mathrm{VO}(\mathrm{IV})>\mathrm{Zr}(\mathrm{IV}) \cong \mathrm{UO}_{2}(\mathrm{VI})>\mathrm{Th}(\mathrm{IV})$. This may be due to the variation of ionic size of the cation.

Table 2. Thermal data of metal complexes.

\begin{tabular}{|c|c|c|c|c|c|c|}
\hline \multirow[t]{2}{*}{ Compound } & \multirow{2}{*}{\begin{tabular}{|c|} 
Half \\
decomposition \\
temperature \\
$\left({ }^{\circ} \mathrm{C}\right)$
\end{tabular}} & \multirow[t]{2}{*}{ Step } & $\begin{array}{c}\text { Activation } \\
\text { energy } \\
\left(\mathrm{kJ} \mathrm{mol}^{-1}\right)\end{array}$ & \multirow{2}{*}{$\begin{array}{l}\text { Frequency } \\
\text { factor } \mathrm{Z} \\
\quad\left(\mathrm{S}^{-1}\right)\end{array}$} & \multirow{2}{*}{$\begin{array}{c}\text { Entropy change } \\
-(\Delta \mathrm{S}) \\
\left(\mathrm{J} \mathrm{mol}^{-1} \mathrm{~K}^{-1}\right)\end{array}$} & \multirow{2}{*}{$\begin{array}{c}\text { Free energy } \\
\text { change } \\
(\Delta \mathrm{G}) \\
\left(\mathrm{kJ} \mathrm{mol}^{-1}\right)\end{array}$} \\
\hline & & & CR* & & & \\
\hline \multirow{2}{*}[\operatorname{VOL}^{1}(\mathrm{H}_{2}\mathrm{O})]{} & \multirow{2}{*}{432} & I & 32.83 & 27.33 & 254.36 & 38.83 \\
\hline & & II & 45.44 & 28.46 & 261.44 & 36.77 \\
\hline \multirow{2}{*}{\begin{tabular}{|l|}
{$\left[\mathrm{Zr}(\mathrm{OH})_{2}\right.$} \\
$\left.\mathrm{L}^{1}\left(\mathrm{CH}_{3} \mathrm{OH}\right)_{2}\right]$
\end{tabular}} & \multirow{2}{*}{485} & I & 34.04 & 37.45 & 242.66 & 31.45 \\
\hline & & II & 50.36 & 28.46 & 275.78 & 33.97 \\
\hline \multirow{2}{*}[\mathrm{Th}(\mathrm{HL}^{1})_{2}(\mathrm{NO}_{3})_{2}]{} & \multirow{2}{*}{405} & I & 38.36 & 35.45 & 268.94 & 45.33 \\
\hline & & II & 51.23 & 42.86 & 274.35 & 42.45 \\
\hline \multirow{2}{*}[\mathrm{UO}_{2}\mathrm{L}^{1}(\mathrm{CH}_{3}\mathrm{OH})]{} & \multirow{2}{*}{460} & I & 36.46 & 29.03 & 235.48 & 38.45 \\
\hline & & II & 49.03 & 32.45 & 269.77 & 42.36 \\
\hline \multirow{2}{*}[\mathrm{VOL}^{2}(\mathrm{H}_{2}\mathrm{O})]{} & \multirow{2}{*}{405} & I & 36.32 & 32.33 & 229.45 & 48.55 \\
\hline & & II & 51.83 & 28.93 & 237.98 & 45.36 \\
\hline \multirow{2}{*}{\begin{tabular}{|l|}
$\mathrm{Zr}(\mathrm{OH})_{2}$ \\
$\left.\mathrm{~L}^{2}\left(\mathrm{CH}_{3} \mathrm{OH}\right)_{2}\right]$ \\
\end{tabular}} & \multirow{2}{*}{428} & I & 35.97 & 45.89 & 282.23 & 33.45 \\
\hline & & II & 45.03 & 40.32 & 292.36 & 31.23 \\
\hline \multirow{2}{*}[\mathrm{Th}(\mathrm{HL}^{2})_{2}(\mathrm{NO}_{3})_{2}]{} & \multirow{2}{*}{460} & I & 25.83 & 38.95 & 284.53 & 29.32 \\
\hline & & II & 50.86 & 35.46 & 289.23 & 30.53 \\
\hline \multirow{2}{*}[\mathrm{UO}_{2}\mathrm{L}^{2}(\mathrm{CH}_{3}\mathrm{OH})]{} & \multirow{2}{*}{468} & I & 29.45 & 32.44 & 283.33 & 28.07 \\
\hline & & II & 48.68 & 38.54 & 289.45 & 31.08 \\
\hline
\end{tabular}

*CR $=$ Coat-Redfern,

Table 3. Antibacterial and antifungal activity of ligands and their complexes.

\begin{tabular}{|c|c|c|c|c|c|c|c|}
\hline \multirow[t]{2}{*}{ Compound } & \multicolumn{5}{|c|}{$\begin{array}{c}\text { Antibacterial activity } \\
\text { zone of inhibition (mm) }\end{array}$} & \multicolumn{2}{|c|}{$\begin{array}{c}\text { Antifungal activity } \\
\text { zone of inhibition (mm) }\end{array}$} \\
\hline & E. coli & S. abony & S. aureus & P. aeruginosa & B.subtilis & A.nigrer & C. albicans \\
\hline $\mathrm{H}_{2} \mathrm{~L}^{1}$ & 10.15 & 14.21 & 11.24 & 12.12 & 12.24 & 10.24 & 10.27 \\
\hline$\left[\operatorname{VOL}^{1}\left(\mathrm{H}_{2} \mathrm{O}\right)\right]$ & 11.25 & 15.61 & 13.45 & 12.42 & 13.65 & 12.22 & 12.34 \\
\hline$\left[\mathrm{Zr}(\mathrm{OH})_{2} \mathrm{~L}^{1}\left(\mathrm{CH}_{3} \mathrm{OH}\right)_{2}\right]$ & 12.12 & 14.28 & 12.48 & 12.18 & 16.24 & 14.22 & 13.12 \\
\hline$\left[\mathrm{Th}\left(\mathrm{HL}^{1}\right)_{2}\left(\mathrm{NO}_{3}\right)_{2}\right]$ & 13.65 & 18.42 & 11.26 & 16.50 & 13.80 & 15.34 & 15.00 \\
\hline$\left[\mathrm{UO}_{2} \mathrm{~L}^{1}\left(\mathrm{CH}_{3} \mathrm{OH}\right)\right]$ & 12.24 & 15.24 & 13.10 & 14.88 & 13.88 & 15.34 & 11.92 \\
\hline $\mathrm{H}_{2} \mathrm{~L}^{2}$ & 12.66 & 12.54 & 12.86 & 12.93 & 12.64 & 10.26 & 10.24 \\
\hline$\left[\operatorname{VOL}^{2}\left(\mathrm{H}_{2} \mathrm{O}\right)\right]$ & 13.58 & 12.56 & 15.44 & 14.54 & 15.60 & 10.95 & 11.24 \\
\hline$\left[\mathrm{Zr}(\mathrm{OH})_{2} \mathrm{~L}^{2}\left(\mathrm{CH}_{3} \mathrm{OH}\right)_{2}\right]$ & 15.52 & 14.66 & 13.88 & 12.96 & 17.42 & 10.42 & 12.44 \\
\hline$\left[\mathrm{Th}\left(\mathrm{HL}^{2}\right)_{2}\left(\mathrm{NO}_{3}\right)_{2}\right]$ & 15.36 & 18.24 & 15.30 & 15.10 & 16.40 & 10.98 & 12.90 \\
\hline$\left[\mathrm{UO}_{2} \mathrm{~L}^{2}\left(\mathrm{CH}_{3} \mathrm{OH}\right)\right]$ & 15.62 & 12.77 & 13.10 & 12.95 & 14.95 & 11.00 & 10.92 \\
\hline
\end{tabular}

\section{Antimicrobial activity}

The free ligands and their complexes were tested for their biological activity against the gram positive bacteria ( $S$. aureus and B. subtilis) and gram negative bacteria (E. coli, S. abony, $P$. aeruginosa) and two fungus $A$. niger and $C$. albicans at a concentration of $100 \mu \mathrm{g} / \mathrm{mL}$ by disc diffusion technique. The results of the antibacterial and antifungal study are given in Table 3 . In a typical procedure, a well was made on the agar medium inoculated with microorganisms. The well was filled with test solution using a micropipette and the plate was incubated at $37{ }^{\circ} \mathrm{C}$ for $48 \mathrm{~h}$. During this period, the test solution diffused and the growth of microorganisms was affected. The antimicrobial activity was estimated on the basis of size of the inhibition zone around the cups. From the results it is concluded that the activity of the ligands was appreciably 
enhanced on complexation with the metal. This may be explained by the chelation theory [32], according to which chelation reduces the polarity of the central metal atom because of partial sharing of its positive charge with the donor groups and possible $\pi$-electron delocalization with the whole chelating ring. This chelation increases the lipophilic nature of the central atom, which favors the permeation of the complexes through the lipid layer of the cell membrane. Compounds inhibit the growth of the fungi and bacteria to a greater extent as concentration is increased.

\section{ACKNOWLEDGEMENTS}

The authors are thankful to SAIF, CDRI Lucknow for recording IR and elemental analysis, RSIC, Nagpur for TG facilities and SAIF, Chennai for recording reflectance spectra, respectively.

\section{REFERENCES}

1. Maurya, R.C.; Verma, R.; Singh, T. Synth. React. Inorg. Met.-Org. Chem. 2010, 33, 309.

2. El-Bahnasawy, R.M.; El-Meleigy, S.E.; El-Tawansi, A. Trans. Met. Chem. 1994, 19, 270.

3. Narang, K.K.; Singh, V.P. Synth. React. Inorg. Met.-Org. Chem. 1997, 7, 721.

4. Mohon, M.; Kumar, M.; Jha, N.K. Inorg. Chem. Acta 1987, 136, 65.

5. Jin, N.Y. J. Coord. Chem. 2012, 65, 4013.

6. Fouda, A.S.; Badr, G.E.; El-Haddad, M.N. J. Korean Chem. Soc. 2008, 2, 124.

7. Maurya, R.C.; Rajput, S. Prog. Crystal Growth \& Characterization of Mater. 2006, 52, 142.

8. El-Boraey, H.A.; Aly, S.A. Synth. React. Inorg. Met.-Org. Chem. 2013, 43, 1130.

9. Syamal, A.; Kumar, D. Indian J. Chem. 1984, 23A, 700.

10. Vogel, A.I. Text Book of Quantitative Inorganic Analysis, Longmans: London; 1986.

11. Verma, R.S.; Imam, S.A. Indian J. Microbiol. 1973, B, 14.

12. Hoa, T.C.P.T.; Hoc, L.V.S. Vietnam Anal. Sci. Soc. 2005, 10, 51.

13. Ali, H.M.; Nadiah, A.H.S.; Puvaneswary, S.; Zain, S.M.; Endom, I. Malesian J. Sci. 2006, $25,99$.

14. Silverstein, R.M.; Bassler, G.C.; Morril, T.C. Spectroscopic Identification of Organic Compounds, John Wiley and Sons: New York; 1981.

15. Wang, H.Y.; Shi, Y.H.; Lu, H.Y. J. Coord. Chem. 2012, 65, 2811.

16. Abdallah, S.M. Arab. J. Chem. 2012, 5, 251.

17. Baligar, R.S.; Revankar, V.K. J. Serb. Chem. Soc. 2006, 71, 1301.

18. Thaker, B.T.; Surati, K.R.; Patel, P.; Parmar, S.D. J. Iranian Chem. Soc. 2006, 3, 371.

19. Jin, N.Y. J. Coord. Chem. 2012, 65, 4013.

20. Maurya, M.R.; Maurya, R.C. Rev. Inorg. Chem. 1995, $15,1$.

21. Curtis, N.F.; Curtis, Y.M. Inorg. Chem. 1965, 4, 404.

22. Kumar, D.; Gupta, P.K.; Syamal, A. J. Indian Chem. Soc. 2003, 80, 3.

23. Ajibade, P.A.; Idemudia, O.G.; Okoh, A.I. Bull. Chem. Soc. Ethiop. 2013, 27, 77.

24. Maurya, M.R.; Khurana, S.; Schuzke, C.; Rehder, D. Eur. J. Inorg. Chem. 2001, 779.

25. Mishra, A.P.; Pandey, L.R. Indian J. Chem. 2005, 44(A), 94.

26. Coats, A.W.; Redfern, J.P. Nature 1964, 201, 68.

27. Mishra, A.P. J. Indian Chem. Soc. 1999, 35, 76.

28. Thankamony, M.; Sindhu, K.B.; Rijulal, G.; Mohanan, K. J. Therm. Anal. Cal. 2009, 1, 259.

29. Bhadja, D.R.; Parsania, P.H. J. Indian Chem. Soc. 2002, 79, 932.

30. Aswar, A.S.; Aswale, S.R.; Mandlik, P.R. Indian J. Chem. 2004, 43A, 1892.

31. Wahed, M.G.A.E.; Metwally, S.M. Mater. Chem. Phys. 2002, 78, 299.

32. Belaid, S.; Landreau, A.; Djebbar, S.; Benali-Baitich, O.; Bouet, G.; Bouchara, J.P. J. Inorg. Biochem. 2008, 102, 63. 